UDC: 159.947 .5

DOI: https://doi.org/10.24195/2414-4665-2017-1-9

Liubov Kuzo,

PhD (Candidate of Psychological Sciences), associate professor, Department of Language Training,

Lviv State University of Internal Affairs, 26, Horodotska Str., Lviv, Ukraine

\title{
MOTIVATIONAL CHARACTERISTICS OF TEMPORAL PERSPECTIVE OF ENGLISH LEARNERS MAJORING IN DIFFERENT SPECIALTIES
}

An important factor of person's behavioral motivation is his/her temporal perspective. The proficiency of English as a foreign language is associated not only with the students' efficiency or intellectual capacity but also depends on their academic motivation. The nature of the events that form the basis of students' temporal perspective determine the direction and content of their activities in the academic studies, initiative, satisfaction with the studies, personal awareness of the importance of new knowledge. The aim of the study is to single out the differences of motivational characteristics of temporal perspective in groups of students who study English according to different curricula. In the research, positive inducers of Nuttin's Motivational Induction Method were used for the explication of structural and semantic features of students' temporal perspective. According to the results obtained, going abroad can be considered as an important motivational factor of learning English. For the most part, excellent students were characterized by desire to go abroad. That is why they have the highest number of motivational objects located in the nearest future, since living abroad is considered to be less predictable due to the lack of students' experience of staying abroad. On the other hand, less successful students, who have more plans localized in the mature period of life, do not plan to immigrate, but strive to obtain abstractly formulated self-realization in Ukraine. Higher number of motivational objects that are peculiar to more successful respondents can be explained by their higher level of diligence, allowing them to study more effectively. On the other hand, this does not exclude greater level of cognitive complexity of the excellent students that allows them to produce greater number of motivational objects and study more successfully. The study proves that the higher is the efficiency of studying, the higher is the number of motivational objects located at the age of 25 years or older. These results prove that the respondents have clearer plans particularly for this period of their lifetime.

Keywords: educational success, motivation, motivation induction, motivational object, temporal perspective, interrelation.

\section{Introduction}

Achieving proficiency in English as a foreign language may not only be associated with the student's working capacity or his/her intellectual abilities, but rather depends on his/her academic motivation. Another important factor of person's behavioral motivation is his/her temporal perspective. The nature of the events forming the basis of students' temporal perspective may determine direction and content of their activity in the educational process, initiative, satisfaction with studies, and personal awareness of the importance of new knowledge. As far as the transformations taking place in the society change external (social) learning motives, social prestige of higher education, importance of having a profession, social demands for specialists of certain areas, students' ideas about their self-realization, empirical data acquired over the past decades do not reflect current state of the outlined problem. Temporal perspective and learning motivation can also be influenced by regional and cultural characteristics of a student.

The findings of numerous research works show that it is impossible to achieve efficient learning only by means of improving teaching methods without paying attention to the motives for learning. In our opinion, it is confirmed by the studies of motives as the source of hu- man activity (B. Ananiev, V. Aseiev, L. Bozhovych, A. Lieontiev, T. Matis, A. Maslow, H. Heckhausen). The researchers investigated peculiarities of structure and development of motivational sphere of student personalities, characterized some basic motives of learning: cognitive interest (N. Talyzina), cognitive need (Ye. Ilin), social and cognitive motives (A. Markova), motives of achievements and failure avoidance (N. Skorokhodova, H. Heckhausen), communicative and creative selfrealization motives (N. Badmaieva). Also, the scientists (V. Aseiev, A. Markova, N. Talyzina) researched the formation of academic motivation, namely, interrelation between learning progress of senior school students and motivational objects of their temporal perspective (I. Riabikina).

The aim of the research is to find out the differences of motivational characteristics of temporal perspective in the groups of students who learn English according to different curricula. The aim involves coping with the following tasks:

- to explore the differences and relationships between temporal perspective and motivation for learning the English language in the groups of students with different majors;

- to define and substantiate the distinctions between 
semantic, structural and dynamic characteristics, estimation of emotional background of temporal perspective by the students with different levels of motivation for learning the English language.

\section{Methodology}

The study was carried out at the premises of Lviv State University of Internal Affairs and Vasyl Stefanyk Precarpathian National University. Empirical sample included 253 respondents. 25 students (10\% of all the respondents under study) did not complete all of the suggested procedures. Therefore, the results of 228 students were analyzed. $18.4 \%$ of the respondents were men (42 people) and $81.6 \%$ - women (186 people). All the respondents were divided into three groups under study. Group No. 1 included students who study English as a discipline of the humanities, namely, first-third-year students obtaining degrees in the following specialties: "Management Psychology", "Practical Psychology", "Economic Security", "Criminal Investigation", and "Social Pedagogy". In total, 112 students who study English during the first years of training along with their specialist disciplines took part in the research. 11 students $(10 \%)$ did not complete all of the suggested procedures. Therefore, the results of 101 respondents, including 33 men $(32.7 \%)$ and 68 women $(67.3 \%)$, were analyzed. The age of people under study ranged from 17 to 21 years $(\mathrm{M}=19 \pm 1)$

Group No. 2 included 82 students who learn English as a discipline of their specialization: first-third-year students majoring in "Primary Education and English". Only 4 of them $(5 \%)$ did not complete all of the suggested methods. Therefore, the results of 78 respondents (all women) aged 17 to 21 years $(M=19 \pm 1)$ were analyzed.

Group No. 3 included 59 respondents learning English as a specialty: first-second-year students majoring in "English Language and Literature". 10 students (20\%) did not complete all of the suggested methods. Therefore, the results of 49 respondents, including 9 men $(18 \%)$ and 40 women $(82 \%)$ aged 17 to 19 years $(M=18 \pm 1)$, were analyzed.

The procedure of the study involved carrying out the suggested procedures by each group of students. Time for completing the tasks was unlimited. The respondents managed to fulfill the tasks completely within an hour.

We used positive inducers of the method of motivational induction by J. Nuttin [9] for explication of structural and semantic peculiarities of temporal perspective of students. There are two stages in motivational induction method. The first stage represents formation of the list of motivational objects for each group of respondents. This method is based on the method of incomplete sentences. We suggested 40 sentences presented in the $1^{\text {st }}$ person singular that were aimed at defining motivational objects of temporal perspective of the respondent's future. The students were asked to complete each sentence formulating the objects that motivate them.

At the second stage, the researcher should carry out the coding of motivational objects, which have been indi- cated by a respondent. Each motivational object obtains two codes - temporal and informative. While processing the results with the help of temporal code, we estimate possible time of the beginning, accomplishment of the event, plan and intention described by the respondent who completes the sentence. In the process of coding procedure, we mark motivational objects according to the calendar periods of the respondent's life. In particular, in order to locate an event in time as accurately as possible, the following symbols are used: $\mathrm{Lf}-$ is used when a person under study indicates his/her whole further life as the unity (e.g. "I would like to live here for the rest of my life") or it is impossible to understand to which life period the objects mentioned by the respondent should be referred to (e.g. "I would like to work as a criminal investigator"); X - refers to objects that are connected with the time of the respondent's death or located in the period after his/her death; $\mathrm{M}$ - events referring to the period from several days to several months; $\mathrm{Y}$ - events that are located in the period from one year to three years; $\mathrm{A}$ - in our study it was used to indicate the events referring to the period beginning with 25 or more years if the respondents marked their localization, otherwise it was marked as Lf. It is explained by the fact that only a few respondents located events in the period of their career. However, in Nuttin's method this category of symbols (A) is divided into several periods.

The main categories of the analysis of the content of motivational induction procedures are as follows: SR (self-realization) - actions or intentions of a person aimed at his/her development (actualization, self-development), which cannot be referred to other (next) categories of the analysis; $\mathrm{C}$ - actions and aspirations of a person referring to personal, family life or expectations/fears of possible loneliness; $\mathrm{C}_{2}$ - purposes formulated as the desire to do something for others ("help one's parents"); $\mathrm{C}_{3}$ - expecting something from others ("I want my parents to understand me"); $\mathrm{R}_{2}$ - work/career; $\mathrm{R}_{3}$ - studies; $\mathrm{R}_{4}$ - this category included objects, in which students expressed their desire to complete the training course, university, get a degree, but did not indicate the necessity for obtaining knowledge, progress in studies; $\mathrm{R}(\mathrm{A})$ - the intention to study English or to use it in future work (this category included objects that had already correlated with $\mathrm{R}_{2}$ or $\mathrm{R}_{3}$, that is why these indexes were not taken into account when estimating general amount of objects); EX - the intention to go abroad for a long period of time (except for tourism); L - activity associated with leisure, game, household; $\mathrm{P}$ - motives related to the desire to possess or achieve something; $\mathrm{Pt}$ - desire for social and political changes. In order to compare the amount of motivational objects, we estimated their number presented by every separate respondent (not all the students completed all of 40 sentence fragments; some respondents indicated several motivational objects in one sentence fragment).

In order to estimate the students' progress in studying the English language, they were asked to indicate a grade they had received for this subject in the previous 
term. Apart from that, taking into consideration the subjective nature of the grade, possibility of using different estimation criteria by English teachers in different student groups, we also used author's grammar tests. The tests were prepared according to the English language curriculum for students of all specialties. The tests provide an opportunity to check integrated mastering of the training content on the basis of combination of lexical and grammar tasks.

The English test consists of four parts: A, B, C, D. Each part contains 5 tasks. All tasks have a typical structure. Task A is a gap-filling task. It suggests completing each sentence with a separate lexical unit according to the context. Task B involves choosing one correct answer; it is based on the grammar material learned at the Intermediate level. There are four options with answers to each sentence and only one answer is correct. Task $\mathrm{C}$ is a mor- phology task; it involves correct determining and creating a derived part of speech from the verb given in brackets according to the context. Task D aims to check the correct use of grammatical forms. In each sentence it is necessary to find and cross an odd lexico-grammatical form. The tasks are estimated according to the scoring system. Each correct answer is given 1 score. Maximum amount of scores for one task is 5. 20-25 minutes are given to do the test. Statistical data processing was done with the help of SPSS 20.

\section{Discussion}

According to the data obtained, the students of English Philology Department who studied it as a specialty showed the best results in the English test; the students studying English as a specialization had sufficiently better results than those who studied English as a discipline of the humanities (Figure 1).

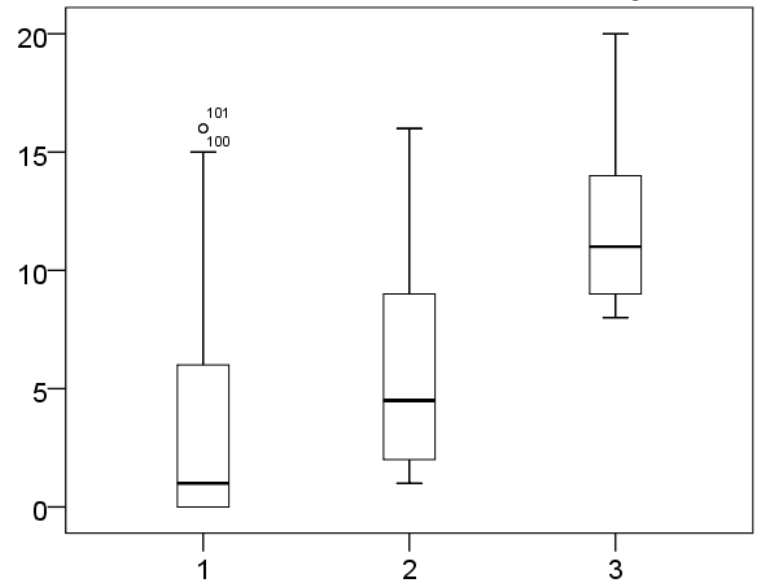

Fig. 1. The indexes of the English grammar test accomplished by the participants of the groups under study

Notes: Down - Results of the English test;

Across - 1-Group No. 1, 2-Group No. 2, 3-Group No. 3

The results obtained in all three groups showed significant interrelation between the level of success of completing the English test and the degree of desire for leisure (L), as well as a negative correlation of the first parameter with the number of motivational objects associated with the desire to finish studies $\left(\mathrm{R}_{4}\right)$. Excellent students were prone to indicate a greater number of events in the expected future (Table 1).

Excellent students who study English as a specialization discipline and the students-philologists showed a common tendency to locate motivational objects in the nearest perspective (within one month and one year). They indicate more objects related to the desire to influence other people $\left(\mathrm{C}_{3}\right)$, future studies $\left(\mathrm{R}_{3}\right)$ and going abroad (EX).

The general sample of the interviewed students (all three groups) points out that the results of the English grammar test successfully correlate with motivational objects located within one month's period of time (M).
Therefore, students with better results of the English test had more detailed plans for the nearest future than their less successful course mates. We noticed the same tendency concerning the amount of plans for studies $\left(\mathrm{R}_{3}\right)$, intent to go abroad (EX), desire for leisure activity (L) (Table 1).

Comparison of indexes of temporal perspective parameters of the interviewed students who learn English as a humanitarian discipline and a specialization (Groups No. 1 and 2 correspondingly) demonstrates the fact that the participants of the third group possess considerably larger amount of motivational objects related to their personal lives/expectations of loneliness (C); expecting something from others (C3); further studying $\left(\mathrm{R}_{3}\right)$, in particular, further learning of English (R_A); intent to go abroad (EX). At the same time, students who learn English as a humanitarian discipline showed much more motivational objects related to self-realization (SR) (Table 2). 
Indexes of correlation between parameters of progress in learning English

Table 1. and temporal perspective of the students from all three groups under study

\begin{tabular}{|c|c|c|c|c|c|c|c|c|}
\hline & & \multicolumn{3}{|c|}{ Progress in English } & \multicolumn{4}{|c|}{ English test result } \\
\hline & Spearman po & $\begin{array}{l}\text { Group } \\
\text { №. } 1\end{array}$ & $\begin{array}{l}\text { Group } \\
\text { №.2 }\end{array}$ & $\begin{array}{r}\text { Group } \\
\text { №.3 }\end{array}$ & $\begin{array}{c}\text { Group } \\
\text { №1 }\end{array}$ & $\begin{array}{l}\text { Group } \\
\text { № } 2\end{array}$ & $\begin{array}{r}\text { Group } \\
\text { №.3 }\end{array}$ & $\begin{array}{l}\text { Total sam- } \\
\text { ple }\end{array}$ \\
\hline $\mathrm{Lf}$ & $\begin{array}{l}\text { correlation coef- } \\
\text { ficient }\end{array}$ &, $268^{* *}$ & &,$- 447^{* * *}$ & & &,$- 465^{* *}$ & \\
\hline $\mathrm{Y}$ & $\begin{array}{l}\text { correlation coef- } \\
\text { ficient }\end{array}$ & & &, $450^{* *}$ & &, $264^{*}$ &, $373^{* *}$ & \\
\hline M & $\begin{array}{l}\text { correlation coef- } \\
\text { ficient. }\end{array}$ & & &, $437^{* *}$ & &, $503^{* *}$ &, $637^{* *}$ &, $268^{* *}$ \\
\hline \multirow[t]{2}{*}{ SR } & \multirow{2}{*}{$\begin{array}{l}\text { correlation coef- } \\
\text { ficient. } \\
\text { correlation coef- } \\
\text { ficient. }\end{array}$} & \multirow[b]{2}{*}{,199* } & & \multirow[t]{2}{*}{,$- 534^{* *}$} &, $214^{*}$ &,$- 293^{* *}$ &,$- 535^{* *}$ & \\
\hline & & & & & & & & \\
\hline \multirow{2}{*}{$\begin{array}{l}\mathrm{C}_{3} \\
\mathrm{R}_{3}\end{array}$} & \multirow{2}{*}{$\begin{array}{l}\text { correlation coef- } \\
\text { ficient.. } \\
\text { correlation coef- } \\
\text { ficient. }\end{array}$} & & ,268* &, $330^{*}$ & & &, $342^{*}$ & \\
\hline & & &, $280^{*}$ &, $333^{*}$ & & &, $343^{*}$ &, $153^{*}$ \\
\hline \multirow{2}{*}{$\begin{array}{l}\mathrm{R}_{\text {_A }} \\
\mathrm{R}_{4}\end{array}$} & \multirow{2}{*}{$\begin{array}{l}\text { correlation coef- } \\
\text { ficient. } \\
\text { correlation coef- } \\
\text { ficient. }\end{array}$} & & &, $301^{*}$ & & & & \\
\hline & &,$- 200^{* *}$ &,$- 226^{*}$ &,$- 363^{*}$ & &,$- 316^{* *}$ &,$- 380^{* *}$ & \\
\hline \multirow{2}{*}{$\begin{array}{l}\text { EX } \\
\text { L }\end{array}$} & \multirow{2}{*}{$\begin{array}{l}\text { correlation coef- } \\
\text { ficient. } \\
\text { correlation coef- } \\
\text { ficient. }\end{array}$} & & \multirow[t]{2}{*}{, $310^{* *}$} &, $541^{* *}$ & & &, $344^{*}$ &, $179^{* *}$ \\
\hline & & & &, $334^{*}$ &, $215^{*}$ &, $310^{* *}$ &, $515^{* *}$ &, $411^{* *}$ \\
\hline \multirow{2}{*}{$\begin{array}{l}\text { Temporal perspec- } \\
\text { tive duration } \\
\text { The number of } \\
\text { events }\end{array}$} & \multirow{2}{*}{$\begin{array}{l}\text { correlation coef- } \\
\text { ficient. } \\
\text { correlation coef- } \\
\text { ficient }\end{array}$} &, $217^{*}$ & \multirow[t]{2}{*}{,$- 322^{* *}$} &,$- 311^{*}$ &, $251^{*}$ &,$- 275^{*}$ & &, $151^{*}$ \\
\hline & &, $285^{* *}$ & &, $464^{* *}$ & &, $281^{*}$ &, $312^{*}$ &, $263^{* *}$ \\
\hline
\end{tabular}

Indexes of statistical differences between the results of Nuttin's method of motivational induction fulfillment by groups of students learning English as a humanitarian discipline (Group No. 1) and as a specialization discipline (Group No. 2)

\begin{tabular}{|c|c|c|c|c|c|c|c|}
\hline \multicolumn{2}{|c|}{ Group №1 and № 2} & SR & $\mathrm{C}$ & $\mathrm{C}_{3}$ & $\mathrm{R}_{3}$ & R_A & EX \\
\hline \multicolumn{2}{|c|}{ Mann-Whitney U } & 1689,5 & 2956,5 & 3030,0 & 2372,5 & 3180,0 & 2487,5 \\
\hline \multicolumn{2}{|c|}{ Wilcoxon W } & 4770,5 & 8107,5 & 8181,0 & 7523,5 & 8331,0 & 7638,5 \\
\hline \multicolumn{2}{|l|}{$\mathrm{Z}$} & $-6,558$ & $-2,873$ & $-2,667$ & $-4,624$ & $-3,308$ & $-5,509$ \\
\hline \multicolumn{2}{|c|}{ Asymptotic value } & ,000 & ,004 & ,008 & ,000 & ,001 & ,000 \\
\hline \multirow[b]{2}{*}{1} & Average & 20,86 & 4,20 & 3,05 & 1,92 & ,19 & ,18 \\
\hline & $\begin{array}{l}\text { Statistical } \\
\text { deviation }\end{array}$ & 6,547 & 3,438 & 2,426 & 2,382 & 809 & 669 \\
\hline \multirow[b]{2}{*}{2} & Average & 14,74 & 5,81 & 3,99 & 3,44 & ,62 & 91 \\
\hline & $\begin{array}{l}\text { Statistical } \\
\text { deviation }\end{array}$ & 3,729 & 4,007 & 2,586 & 2,431 & 1,131 & 1,271 \\
\hline
\end{tabular}

Students-philologists (Group No. 3) are more likely to locate motivational objects of their temporal perspective within the period of 1 year (Y) and after graduation from Science and Education, 2017, Issue 1 higher educational institution $\left(\mathrm{A}_{0}\right)$ compared to the respondents from the group No. 1; they also indicate more motivational objects related to their future studying $\left(\mathrm{R}_{3}\right)$, in particu- 
lar, further learning of English (R_A); intent to go abroad $(\mathrm{EX})$, obtaining benefit or material values $(\mathrm{P})$, leisure $(\mathrm{L})$, social and political aspirations $(\mathrm{Pt})$. However, the respond- ents from the Group No. 1 more frequently referred to the motivational objects related to their whole life (Lf) and connected with personal self-realization (SR) (Table 3).

Table 3.

Indexes of statistical differences between the results of Nuttin's method of motivational induction fulfillment by groups of students learning English as a humanitarian discipline (Group No. 1) and students majoring in "English Language and Literature" (Group No. 3)

\begin{tabular}{|c|c|c|c|c|c|c|c|c|c|c|}
\hline & $1-3$ & $\mathrm{Lf}$ & $\mathrm{Y}$ & $\mathrm{A}_{0}$ & SR & $\mathrm{R}_{3}$ & R_A & EX & $\mathrm{L}$ & $\mathrm{Pt}$ \\
\hline $\mathrm{Ma}$ & n-Whitney U & 1896,5 & 1139,5 & 1818,0 & 1283,5 & 1375,5 & 412,5 & 433,5 & 1182,0 & 1462,0 \\
\hline $\mathrm{Wi}$ & oxon W & 3121,5 & 6290,5 & 6969,0 & 2508,5 & 6526,5 & 5563,5 & 5584,5 & 6333,0 & 6613,0 \\
\hline $\mathrm{Z}$ & & $-2,324$ & $-5,546$ & $-2,739$ & $-4,779$ & $-4,475$ & $-9,652$ & $-9,556$ & $-5,271$ & $-4,824$ \\
\hline Asy & mpt. value & ,020 & ,000 & ,006 & ,000 & ,000 & ,000 & ,000 & ,000 & ,000 \\
\hline & Average & 33,56 & ,96 & 1,28 & 20,86 & 1,92 & ,19 & , 18 & 1,91 & ,33 \\
\hline 1 & \begin{tabular}{|l|} 
Statistical \\
error
\end{tabular} & ,608 &, 116 & , 182 &, 651 & ,237 &, 080 & ,067 & ,223 & ,077 \\
\hline & $\begin{array}{l}\text { Statistical } \\
\text { deviation }\end{array}$ & 6,106 & 1,166 & 1,834 & 6,547 & 2,382 & ,809 & ,669 & 2,245 & ,776 \\
\hline & Average & 32,69 & 2,29 & 1,65 & 15,73 & 3,24 & 1,90 & 1,90 & 3,55 & ,82 \\
\hline 3 & $\begin{array}{l}\text { Statistical } \\
\text { error }\end{array}$ & ,516 & , 193 &, 183 & ,612 & ,273 &, 163 &, 155 & ,259 &, 104 \\
\hline & $\begin{array}{l}\text { Statistical } \\
\text { deviation }\end{array}$ & 3,613 & 1,354 & 1,284 & 4,281 & 1,910 & 1,141 & 1,085 & 1,815 &, 727 \\
\hline
\end{tabular}

In comparison to the students majoring in "English Language and Literature", the students who learn English as a specialization discipline indicated more motivational objects associated with personal life/loneliness (C), expecting something from others $\left(\mathrm{C}_{3}\right)$. Meanwhile, the students-philologists more often locate their motivational objects within the period of 1 year $(\mathrm{Y})$; they indicate much more objects related to their desire to continue learning English in future (R_A), going abroad (EX), leisure $(\mathrm{L})$, obtain material benefit or values $(\mathrm{P})$, social and political aspirations (Pt) (Table 4). groups of students learning English as a specialization discipline (Group No. 2) and as a specialty (Group No. 3)

\begin{tabular}{|c|c|c|c|c|c|c|c|c|c|}
\hline \multicolumn{2}{|c|}{ Group № 2 and 3} & $\mathrm{Y}$ & $\mathrm{C}$ & $\mathrm{C}_{3}$ & R_A & EX & $\mathrm{L}$ & $\mathrm{P}$ & $\mathrm{Pt}$ \\
\hline \multicolumn{2}{|c|}{ Mann-Whitney U } & 608,0 & 1377,5 & 1330,0 & 753,0 & 953,5 & 1068,0 & 1406,0 & 1022,0 \\
\hline \multicolumn{2}{|c|}{ Wilcoxon W } & 3689,0 & 2602,5 & 2555,0 & 3834,0 & 4034,5 & 4149,0 & 4487,0 & 4103,0 \\
\hline \multicolumn{2}{|l|}{$\mathrm{Z}$} & $-6,706$ & $-2,660$ & $-2,910$ & $-6,131$ & $-4,941$ & $-4,244$ & $-2,626$ & $-5,246$ \\
\hline \multicolumn{2}{|c|}{ Asympt. value } &, 000 & ,008 &, 004 & , 000 &, 000 & ,000 & ,009 &, 000 \\
\hline \multirow{3}{*}{2} & Average & ,67 & 5,81 & 3,99 & ,62 & ,91 & 2,18 & ,96 &, 24 \\
\hline & Statistical error & ,089 &, 454 & ,293 & 128 & 144 & ,207 & , 133 & 073 \\
\hline & $\begin{array}{l}\text { Statistical } \\
\text { deviation }\end{array}$ &, 784 & 4,007 & 2,586 & 1,131 & 1,271 & 1,829 & 1,178 & ,648 \\
\hline \multirow{3}{*}{3} & Average & 2,29 & 3,88 & 2,67 & 1,90 & 1,90 & 3,55 & 1,43 &, 82 \\
\hline & Statistical error &, 193 & ,380 & ,239 &, 163 &, 155 & ,259 & , 165 &, 104 \\
\hline & $\begin{array}{l}\text { Statistical } \\
\text { deviation }\end{array}$ & 1,354 & 2,659 & 1,676 & 1,141 & 1,085 & 1,815 & 1,155 & ,727 \\
\hline
\end{tabular}

\section{Conclusions}

It should be taken into consideration that the sample under study consists of students who are getting degrees in different specialties. Consequently, before enrollment they had undergone testing in different subjects. In particular, unlike other students, future students-philologists (English Language and Literature) had to pass External Independent Testing in the English language and demonScience and Education, 2017, Issue 1 strate good command of it. Therefore, it is possible to assume that the students majoring in "English Language and Literature" may have different motivation for learning English and their average level of the language can be much higher than that of other respondents.

Apart from the abovementioned, the curriculum for students-philologists (Group No. 3) provides more academic hours in English than for the students of other 
groups under study. The curriculum for students of the Group No. 2 provides more academic hours in English than the curriculum for students of the Group No. 1 but less than for students-philologists.

Comparison of the existence and direction of the correlation relationships between three groups under study allows us to draw conclusions about the presence of common traits and differences of these relationships between the groups of students of different specialties. Greater number of motivational objects peculiar to more successful respondents can be explained by their higher level of diligence, allowing them to study more effectively. On the other hand, this does not exclude greater level of cognitive complexity of the excellent students that allows them to produce higher number of motivational objects and study more successfully. It was revealed that the higher is the efficiency of learning, the higher is the number of motivational objects located at the age of 25 years or older. These results prove that the respondents have clearer plans particularly for this period of lifetime. This also corresponds to the existence of a positive correlation between the level of grammar test success and the number of motivational objects located within the period of several months or a year. It can be concluded that progress in learning English in the groups of students under the research depends to a greater extent on their goals which are located temporally in the nearest future.

The intent to go abroad, which characterizes excellent students, may be considered as an important motivational factor for learning English. That is why they indicate the greatest number of motivational objects located in the nearest future, since living abroad can be imagined as less predictable due to the lack of corresponding experience. On the other hand, less successful students, who have more plans localized in the mature period of life, do not plan to immigrate but strive to obtain abstractly formulated self-realization in Ukraine.

It has been proved that students with different levels of motivation for learning English differ significantly in the content, structural and dynamic characteristics of their temporal perspective. In our opinion, discovered differences in

\section{REFERENCES}

1. Ananyev, B. H. (2002). Chelovek kak predmet poznaniya [A human as an object of cognition]. St. Petersburg: Piter [in Russian].

2. Aseyev, V. H. (1976). Motivatsiya povedeniya formirovanie lichnosti [Behavioural motivation in personality formation]. Moscow: Mysl [in Russian].

3. Badmayeva, N. Ts. (2004). Vliyanie motivatsyonnogo faktora na razvitie umstvennykh sposobnostey: mongrafiya [The influence of motivational factor on the development intellectual abilities: monograph]. Ulan-Ude [in Russian].

4. Bozhovych, L. I. (1972). Problema razvytyia motyvatsyonnoi sfery rebenka [The development of a child's motivational sphere]. Izucheniye motivatsii povedeniya detey $i$ podrostkov - The study of behavior the characteristics of the temporal perspective can serve as markers that make it possible to predict the formation of certain types of English learning motivation in students getting degrees in different fields of study and their level of success with this discipline. Thus, according to the data obtained, the results of the English test were significantly better in the groups of respondents who learn English as a professional discipline. In particular, the best results were demonstrated by the students majoring in English philology. This group is also characterized by internal motivation for learning English. The results point out that motives of getting education and receiving profession are not heterogeneous. Motives of getting a profession prevail in groups of students who do not study English profoundly. Students who learn English as a humanitarian discipline are characterized by a shorter temporal perspective, motivational objects related to personal self-realization but less related to future studies. Students majoring in English philology indicated more motivational objects located within the period of up to 1 year and objects related to leisure, social and political aspirations, income or property, future work/career. The number of motivational objects associated with the desire to continue learning English and go abroad significantly increases in the groups of respondents who study English as a specialty discipline.

It should be noted that the acquired results prove the hypothesis that students with different motivation of learning English significantly differ by the content, structural and dynamic characteristics of their temporal perspective, which can predict the formation of certain types of motivation for learning the English language in three groups of students and the level of success with the discipline.

We can assume that the changes in these tendencies are possible due to changing political and economic conditions of students' lives. As far as the peculiarities of temporal perspective may depend on a person's age, our results must be tested on the sample of the representatives of other age groups. The results may also depend on the economic conditions, cultural and legal norms of the society that the respondents belong to. Experimental developments in this area remain relevant.

motivation of children and adolescents. (pp. 7-440). Moscow: Pedagogika [in Russian].

5. Ilin, Ye. P. (2000). Motivatsiya i motivy [Motivation and motives]. St. Petersburg: Piter [in Russian].

6. Leontyev, A. N. (1983). Deyatelnost. Soznaniye. Lichnost [Activities. Consciousness. Personality]. Izbrannye psikhologicheskiye proizvedeniya. (Vols. 2). Moscow: Pedagogika [in Russian].

7. Markova, A. K., Matis, T. A., \&. Orlov, A. B. (1990). Formirovaniye motivatsii ucheniya [The formation of motivation for learning]. Moscow: Prosvescheniye [in Russian].

8. Maslow, A. (2008). Motivatsyia i lichnost [Motivation and a personality]. St. Petersburg: Piter [in Russian]. 
9. Nuttin, J. (2004). Motivatsyia, deystviye i perspektiva buduschego [Motivation, activity and future prospects]. Moscow: Mysl [in Russian].

10. Riabykina, Y. V. (2007). Strukturnaya organizatsiya vremennoy perspektivy starsheklassnikov s raznym urovnem uchebnoy uspeshnosti [Structural organization of temporal perspective of senior school students with different level of academic progress]. Extended $a b$ stract of candidate's thesis. St. Petersburg. Retrieved from:

http://www.scholar.ru/speciality.php?page=2\&spec_id=3 [in Russian].

\section{ЛІТЕРАТУРА}

1. Ананьев Б. Г. Человек как предмет познания / Б. Г. Ананьев. - СПб. : Питер, 2002. - 288 с.

2. Асеев В. Г. Мотивация поведения и формирование личности / В. Г. Асеев. - М. : Мысль, 1976. $157 \mathrm{c}$.

3. Бадмаева Н. Ц. Влияние мотивационного фактора на развитие умственных способностей : монография / Н. Ц. Бадмаева. - Улан-Удэ, 2004. - 186 с.

4. Божович Л. И. Проблема развития мотивационной сферы ребенка // Изучение мотивации поведения детей и подростков / Л. И. Божович. - М. : Педагогика, 1972. - С. 7-44.

5. Ильин Е. П. Мотивация и мотивы / Е. П. Ильин. - СПб : Питер, 2000. - 512 с.

6. Леонтьев А. Н. Деятельность. Сознание. Личность / А. Н. Леонтьев // Избранные психологические произведения : в 2-х т. - Т. 2. - М. : Педагогика, 1983. -328 c.

7. Маркова А. К. Формирование мотивации учения : кн. для учителя / А. К. Маркова, Т. А. Матис, А. Б. Орлов. - М. : Просвещение, 1990. - 192 с.
11. Skorokhodova, N. M. (2004). Motivatsiya kak sistema stimulov [Motivation as a system of stimuli]. Selskaya shkola - Rural school, 1, 101-106 [in Russian].

12. Talyzyna, N. F. (1988). Formirovaniye poznavatelnoy deyatelnosti uchaschikhsya [The formation of students' cognitive activity]. Moscow: Prosveshcheniye [in Russian].

13. Heckhausen, H. (1986). Motivatsiya i deyatelnost [Motivation and activity]. (Vols. 1). Moscow: Pedagogika [in Russian].

8. Маслоу А. Мотивация и личность / А. Маслоу ; пер. с англ. - СПб : Питер, 2008. - 352 с.

9. Нюттен Ж. Мотивация, действие и перспектива будущого / Ж. Нюттен. - М. : Смысл, 2004. $608 \mathrm{c}$.

10. Рябикина И. В. Структурная организация временной перспективы старшеклассников с разным уровнем учебной успешности : автореф. на соиск. учен. степени канд. психол. наук : 19.00.07 «Педагогическая психология» / И. В. Рябикина. - СПб, 2007. 20 c. - Режим доступа : http://www.scholar.ru/speciality.php?page=2\&spec_id=3.

11. Скороходова Н. М. Мотивация как система стимулов / Н. М. Скороходова // Сельская школа. 2004. - № 1. - C. 101-106.

12. Талызина Н. Ф. Формирование познавательной деятельности учащихся : книга для учителя / Н. Ф. Талызина. - М. : Просвещение, 1988. - 173 с.

13. Хекхаузен Х. Мотивация и деятельность / Х. Хекхаузен ; пер. с нем. в 2 т. - М. : Педагогика, 1986. - T.1. -408 c.

\section{кандидат психологічних наук, дочент кафедри мовної підготовки, Львівський державний університет внутрішніх справ, \\ МОТИВАЦЙНІ ХАРАКТЕРИСТИКИ ЧАСОВОЇ ПЕРСПЕКТИВИ СТУДЕНТІВ 3 РІЗНИМ РІВНЕМ ФАХОВОГО ВИВЧЕННЯ АНГЛІЙСЬКОЇ МОВИ}

Любов Іванівна Кузьо, вул. Городоиька, 26, м. Львів, Украӥна

Досягнення високого рівня знань англійської мови як іноземної може бути пов'язане не стільки 3 працездатністю студента чи його інтелектуальними можливостями, скільки залежати від його навчальної мотивації. Поряд із цим, важливим фактором мотивації поведінки суб'єкта є його часова перспектива. Характер подій, які знаходяться в основі часової перспективи студента, може визначати спрямованість та зміст його активності в начальному процесі, ініціативність, активність, задоволеність навчанням, усвідомлення особистісної значущості здобуття нових знань. Метою нашого дослідження є виокремлення відмінностей мотиваційних характеристик часової перспективи у групах студентів із різним фаховим рівнем вивчення англійської мови. Для експлікації структурно-змістових особливостей часової перспективи студентської молоді нами було використано позитивні індуктори методики мотиваційної індукції Ж. Нюттена. Порівняння отриманих результатів показників параметрів свідчить про переважання у студентів-відмінників прагнень виїхати за кордон, що можна вважати важливим мотиваційним чинником вивчення англійської мови. Імовірно, саме цим якраз і зумовлена наявність у відмінників більшої кількості мотиваційних об'єктів, які локалізовані у найближчому майбутньому, оскільки життя за кордоном може уявлятись як менш прогнозоване внаслідок відсутності у студентів досвіду перебування там. Менш успішні студенти, які мають більше планів, що локалізовані в періоді дорослого життя, не планують еміграції, більшою мірою прагнучи здобути абстрактно сформульовану ними самореалізацію в Україні. Більша 
кількість мотиваційних конструктів, яка притаманна більш успішним респондентам, може бути пояснена, імовірно, вищим рівнем старанності, що дозволяє їм також більш успішно вчитись. 3 іншого боку, це не виключає наявності більшого рівня когнітивної складності відмінників, що і дозволяє їм продукувати більшу кількість мотиваційних об’єктів і більш успішно вчитись. Тенденція зростання при вищій успішності кількості мотиваційних об'єктів, які локалізовані у віці від 25 і більше років може свідчити про наявність більш чітких планів цих респондентів у цьому періоді їх життя.

Ключові слова: навчальна успішність, мотивація, мотиваційна індукція, мотиваційний об'єкт, часова перспектива, взаємозв'язок.

Reviewed by Doctor of Psychology, prof. Z. Kovalchuk

Submitted on January, 20, 2017

UDC: 159.954 .2 .018

DOI: https://doi.org/10.24195/2414-4665-2017-1-10

\author{
Anastasiia Sannikova, \\ PhD (Candidate of Psychological Sciences), lecturer, \\ Department of Solo Singing, \\ Odessa National Music Academy named after A. V. Nejdanova, \\ 63, Novoselskoho Str., Odessa, Ukraine
}

\title{
SEARCHING FOR INDIVIDUAL DIFFERENCES IN EXPERIENCING PSYCHOLOGICAL BARRIERS
}

The paper aims to present the results of the study of the individual-psychological specificity of experiencing stage barriers by performers who differ in emotional disposition. The stage barrier in the paper is understood as negatively colored intellectual, somatic, emotional and behavioral reactions and experiences that manifest themselves in inhibition, stupor, restriction of choice and in the occurrence of such subjectively insurmountable obstacles that block the stage activity, impede success and can be overcome only in the process of certain kind of psychological work. Emotionality was chosen as a psychological factor that influences the structure of the stage barrier and the specifics of its manifestations. The study of a stable proneness to stage barriers was carried out with the help of the author's psychometric technique "Differential Diagnostics of the Propensity for Stage Barriers", in addition, the "Four Modalities Questionnaire of Emotionality" was used. The significant differences were found with the help of Student's t-test between the group of individuals with the domination of positive emotions of the "joy" pattern, on the one hand, and the rest of the groups with negative emotions domination - "anger", "fear", and "sadness". At the same time, the manifestations of stage barriers in the three groups of individuals with the dominance of negative emotions are considered to be very similar. Therefore, emotionality also affects the specificity of stage barriers. It can be assumed that the features of the emotions that accompany stage barriers, expression, behavior, the peculiarities of their control and regulation, the choice of ways of behavior aimed at inhibiting stage barriers (and perhaps their aggravation) also are different in persons with different emotional dispositions.

Keywords: emotionality, dispositions, joy, anger, fear, sadness, individual differences, psychological barrier, stage barrier.

\section{Introduction}

Stage excitement covers two groups of states that differ in their purposefulness and localization: the locus is "placed" either in the space of experiences of the stage character played by the performer, or in the space of his/her own experiences. It is the artist's experiences related to stage activities that are examined in this study.

In the scientific literature, these states are considered to be tension, stress, stage fever, nervous excitement, severe anxiety, etc. $[2 ; 3 ; 7 ; 8 ; 10 ; 11 ; 12]$. Stage discomfort destructively affects the characteristics of performer's stage activities, the emotional and artistic level of performance of a musical work and causes the emergence of stage barriers.
The stage barrier in the paper is understood as negatively colored intellectual, somatic, emotional and behavioral reactions and experiences that manifest themselves in inhibition, stupor, restriction of choice and in the occurrence of such subjectively insurmountable obstacles that block the stage activity, impede success and can be overcome only in the process of certain kind of psychological work.

The stage barrier as an objective phenomenon demonstrates the divergence of goals and results of performing activities; as a subjective phenomenon is manifested in stage experiences of a different kind; as a psychological phenomenon exists only in the stage (public) activity of the performer. It is in this that the unity in which the processes, states 